\title{
Determinants of Member Participation at Koperasi Karya Utama Nusantara (Kopkun) Purwokerto
}

\author{
By: \\ Fega Prasadini ${ }^{1)}$, Hary Pudjianto $\left.{ }^{1 *}\right)$, Herman Sambodo ${ }^{1)}$ \\ ${ }^{1)}$ Faculty of Economics and Business, Jenderal Soedirman University \\ ${ }^{*}$ Corresponding Author: harrypudj_mm@yahoo.co.id
}

Submissions: 25 June 2019, Accepted: 14 August 2019

\begin{abstract}
This study aimed to examine the effect of member income, length of membership, education level, and distance of residence on member participation of Koperasi Karya Utama Nusantara (Kopkun). Respondents were selected using cluster random sampling. Data were analyzed using multiple regression. This study used a mixed method (quantitative and qualitative approaches). The results indicated that member income, length of membership, and education level had a significant effect on member participation, while the distance of residence did not have an effect on the member participation. The results indicated that in order to increase member participation, Kopkun should improve its services such as providing more items, giving bonuses or benefits to members, providing education about cooperative and involving old and new members in making decisions and policies.
\end{abstract}

Keywords: Cooperative, Mixed Method, Distance of Residence.

\begin{abstract}
ABSTRAK
Penelitian ini bertujuan untuk menguji pengaruh pendapatan, lama keanggotaan, tingkat pendidikan, dan jarak tempat tinggal terhadap partisipasi anggota Koperasi Karya Utama Nusantara (Kopkun). Responden dipilih menggunakan cluster random sampling. Data dianalisis dengan regresi berganda. Penelitian ini menggunakan metode campuran (pendekatan kuantitatif maupun kualitatif). Hasil penelitian menunjukkan bahwa pendapatan, lama keanggotaan, dan pendidikan memiliki pengaruh yang signifikan terhadap partisipasi anggota, sedangkan jarak tempat tinggal tidak mempengaruhi partisipasi anggota. Hasilnya menyiratkan bahwa untuk meningkatkan partisipasi anggota, Kopkun harus meningkatkan layanannya seperti menyediakan barang yang lebih lengkap, memberikan bonus atau manfaat kepada anggota, memberikan pendidikan koperasi dan melibatkan anggota lama serta anggota baru dalam membuat keputusan dan kebijakan.
\end{abstract}

Kata Kunci: Koperasi, Metode Campuran, Jarak Tempat Tinggal.

\section{INTRODUCTION}

Cooperative is a business entity whose activities are based on the principles of kinship, that have members of individual or cooperative legal entities, as people economic movemen. Cooperatives encourage the achievement of a just and prosperous society both materially and spiritually which then embody development as stated in the opening of the 1945 Constitution (Firdaus, 2002: 37). Cooperatives provide benefits to members in particular and to society in general. The existence of cooperatives makes the price of items lower and affordable for the middle to lower class. 
The role of cooperatives in developing countries can be seen from the number of cooperatives, number of members, amount of wealth and number of businesses. According to the Central Statistics Agency (2016), the number of cooperatives in Indonesia from 2013 to 2016 continued to increase from $203,701.00$ to $21,135.00$, but its growth decreased from 4.10 percent in 2013 to 3.67 percent in 2016 . Likewise, number of members, capital, business volume, the remainder of proceeds (SHU) continued to increase from year to year.

The number of cooperatives in Central Java Province increased by 233 units from 2015-2016, while the number of cooperatives in Central Java Province decreased by 2,554 units from 2016-2017. However, members of cooperatives, labor absorption, capital, business volume and amount of SHUs from 2015-2017 continued to increase. In the Banyumas region, the number of cooperatives from 2015 to 2017 has increased every year. However, the increasing number of cooperatives was small every year. The number of cooperatives increased by only 1.3 percent from 2015 to 2016 and increased by 7.1 percent from 2016 to 2017.

Member participation is very important for the progress and success of a cooperative because the business owner is also a consumer, so that the active participation of its members will be able to encourage the cooperative to achieve success. This is in accordance with a study conducted by Hendar (2010: 166) stating that member participation plays a role to determine the success of the cooperative, without the role of the members, the cooperative cannot run effectively and efficiently. One of the cooperatives in Banyumas Regency is Koperasi Karya Utama Nusantara (Kopkun) established on October 18, 2006 which was initially in the form of Cooperative of Unsoed Campus. One of the driving factors of the development of Kopkun Cooperative is the participation of cooperative members. According to comparative data of Kopkun for 2016-2017, self-service transactions, principal savings and mandatory savings, other deposits (daily, special and time deposits) and member investment in general from year to year have increased.

Table 1. Development of Kopkun Member Participation

\begin{tabular}{lcrr}
\hline \multirow{2}{*}{ Data Description } & \multirow{2}{*}{ Unit } & \multicolumn{2}{c}{ Year } \\
\cline { 3 - 4 } & & \multicolumn{1}{c}{2016} & 2017 \\
\hline Number of members & Member & 1105.0 & 1282 \\
Self-service transaction & Rp Million & 894.0 & 1478 \\
Mandatory and principal savings & Rp Million & 360.0 & 530 \\
Other deposits & Rp Million & 338.5 & 818 \\
Member investment & Rp Million & 80,0 & 350 \\
\hline
\end{tabular}

Source: Kopkun Management Accountability Report in 2017

Kopkun Cooperative does not only have advantages in developing its business, but also has some disadvantages. Based on interviews with the Kopkun manager, there are some shortcomings in Kopkun cooperatives; first, the service to its members is considered lacking because each member has different needs. Kopkun members consist of various professions such as civil servants, private employees, entrepreneurs, and students. Each member with different profession certainly has different needs where these needs have not all been fulfilled by the cooperative. Second, service for students have not been optimal because the students only received loans in amount in accordance with the amount of their deposits.

Several previous studies on cooperatives have been carried out, both using quantitative and qualitative research methods. A study using qualitative method was conducted by Morrow (2004). The study found that trust has a positive effect on member performance. Previous studies using quantitative research method were conducted by Valentinov (2007), Zivkovic, et al (2017), and J. Glew (1995). Their studies using quantitative methods were mostly about the effect of members' abilities on the level of participation. Most studies indicated that the variables such as education level, member motivation, distance of residence, and income have a positive effect on member participation. 
Unlike the previous studies, this study used a mixed method. Mixed methods research combines qualitative and quantitative research methods. The type of method used in this study was an explanatory sequential mixed method, where the researcher collected qualitative data followed by conducting quantitative survey. According to Slamet (1994: 137), cooperative member participation is affected by education level, member income, and length of membership.

Sari (2011) found that member income has a positive effect on cooperative member participation. Maya (2011) found that length of membership has a positive effect on member participation. Meilani (2002) found that education level has a positive effect on member participation. In addition, based on central place theory, a market location can affect level of consumer purchases. In this study, the cooperative acts as a market, while the members act as consumers, this means that the closer the location of cooperative to members, the higher the level of member participation in terms of buying and selling.

There were several problems at Koperasi Karya Utama Nusantara (Kopkun) relating to participation such as the lack of members awareness in attending RAT (Annual Member Meeting), members who were busy with their respective activities, high number of members with low education, etc.

Member participation is assumed to be affected by several factors such as income, distance of residence, education level and length of membership. This study aimed to examine whether income, length of membership, education level, and distance of residence have an effect on member participation of Koperasi Karya Utama Nusantara (Kopkun) and to identify the most influential variable.

\section{METHOD}

This study used a mixed methods research. Mixed methods research is a research approach integrating quantitative and qualitative data, using different designs, combining two forms of data, which can involve philosophical assumptions and theoretical frameworks (Creswell, 2016: 5). There are two types of data sources used in this study, namely primary data and secondary data. Primary data were obtained by conducting questionnaires-based interview to the members of Koperasi Karya Utama Nusantara (Kopkun). Secondary data were obtained from written data such as archives and records of Koperasi Karya Utama Nusantara (Kopkun) relevant to the study.

Population in this study were all 1,343 members of Koperasi Karya Utama Nusantara (Kopkun). Determination of respondents based on member professions classified into four groups, namely civil servant, private employee, entrepreneur and student was taken proportionally using the Slovin formula. The technique used in this study was cluster random sampling technique.

Table 2. Sample Size

\begin{tabular}{lccc}
\hline \multicolumn{1}{c}{ Member Profession } & Population & Sampling & Sample Size \\
\hline Civil Servant & 378 & $(378: 1.343) \times 93$ & 26 \\
Private Employee & 135 & $(135: 1.343) \times 93$ & 9 \\
Entrepreneur & 100 & $(100: 1.343) \times 93$ & 6 \\
College Student & 454 & $(454: 1.343) \times 93$ & 31 \\
\hline \multicolumn{1}{c}{ Total } & 1.343 & & 72 \\
\hline
\end{tabular}

Source: Primary Data Processed (Eviews 9)

Data analysis technique used in this study was multiple regression. In this study, multiple regression was used to determine the effect of income $\left(X_{1}\right)$, length of membership $\left(X_{2}\right)$, education level $\left(X_{3}\right)$ and distance of residence $\left(X_{4}\right)$ on level of participation of cooperative members $(Y)$. One of the requirements for multiple linear regression is to perform classical assumption tests consisting of multicollinearity test, normality test, heterocedasticity test, and autocorrelation test. The equation is as follows:

$$
\gamma=a+\beta_{1} X_{1}+\beta_{2} X_{2}+\beta_{3} X_{3}+\beta_{4} X_{4}+e
$$

$Y$ is member participation (person), $\alpha$ is constant, $X_{1}$ is member income (IDR), $X_{2}$ is length of 
membership (month), $X_{3}$ is education level (last education), $X_{4}$ is distance of residence (kilometer), $\beta$ is regression coefficient of each variable, and $\mathrm{e}$ is disturbance error.

To determine whether or not there is a relationship between the independent variable and the dependent variable partially or simultaneously, this study uses hypothesis testing, namely $\mathrm{F}$ test, $\mathrm{t}$ test, and coefficient of determination. Whereas to analyze the most influential variable on member participation at Koperasi Karya Utama Nusantara (Kopkun), elasticity test is systematically formulated in the following equation (Gujarati, 2003: 223):

$$
E_{i}=\beta_{i} \frac{X_{1}}{Y}
$$

$E$ is elasticity on member participation, $\beta$ is coefficient, $Y$ is average value of dependent variable, and $\mathrm{X}$ is average value of independent variable.

\section{RESULT AND DISCUSSION}

Before conducting multiple linear regression, one of the requirements is to perform classical assumption tests consisting of multicollinearity test, normality test, heterocedasticity test, and autocorrelation test. After conducting classical assumption tests, it was obtained the result of Multicollinearity Test as follows.

Table 3. Multicollinearity Test

\begin{tabular}{lcc}
\hline & Variable & VIF \\
\hline Member Income & 1.040 \\
Length of Membership & 1.004 \\
Education Level & 1.049 \\
Distance of Residence & 1.019 \\
\hline
\end{tabular}

Source: Primary Data Processed (Eviews 9)

Based on Table 3, it can be seen that VIF value ranges from 1.0049264 to 1.049264 , meaning that the overall regression results have a VIF value $<10$. Thus, the regression model does not indicate symptoms of multicollinearity.

Normality Test in this study was performed using the Jarque-Bera Test. The test obtained the following results, the value of Jarque-Bera (JB) test is 5.340 and the value of error of significanse 0.069 , meaning that it is greater than 0.05 . This indicates that the data in this study have met the assumptions of normality.

Heteroscedasticity test in this study was performed using the Glejser Test. The test obtained the following results.

Table 4. Heteroscedasticity Test

\begin{tabular}{llll}
\hline F-statistic & 1.453 & Prob. F(4,67) & 0.226 \\
Obs*R-squared & 5.748 & Prob. Chi-Square(4) & 0.218 \\
Scaled explained SS & 4.790 & Prob. Chi-Square(4) & 0.309 \\
\hline
\end{tabular}

Source: Primary Data Processed (Eviews 9)

Based on Table 4, it can be seen that the probability value of Obs*R-squared is $5.74>0.05$. Thus, it can be concluded that the regression model in this study does not have an heteroscedasticity problem statistically.

Autocorrelation test in this study was performed using the Durbin Watson Test method (DW test). The test obtained the following results. 


\begin{tabular}{ccccccc:c}
$\mathrm{d}_{\mathrm{L}}$ & $\vdots$ & $\mathrm{d}$ & $\mathrm{dw}$ & & $4-\mathrm{d}_{\mathrm{U}}$ & $4-\mathrm{d}_{\mathrm{L}}$ \\
\hline 1.502 & \multirow{2}{*}{1.736} & & 1.865 & $\vdots$ & 2.263 & 2.497
\end{tabular}

Figure 1. Autocorrelation Test

Source: Primary Data processed (Eviews 9)

Based on Figure 1, it can be seen that the Durbin Watson value is 1.8654 , which is between the $d_{u}$ value and $4-d_{u}$ value. Thus, it can be concluded that the regression model does not have an autocorrelation problem statistically.

After conducting the classical assumption tests, multiple regression analysis was performed to determine the effect of the independent variable, namely member participation on the dependent variables, namely member income, length of membership, education level, and distance of residence. The followings are the results of multiple regression analysis.

Table 5. Multiple Linear Regression

\begin{tabular}{lccc}
\hline \multicolumn{1}{c}{ Variable } & Coefficient & Std. Error & P Value \\
\hline Member income $\left(\mathrm{X}_{1}\right)$ & -0.502 & 0.231 & 0.033 \\
Length of membership $\left(\mathrm{X}_{2}\right)$ & -0.051 & 0.024 & 0.042 \\
Education level $\left(\mathrm{X}_{3}\right)$ & 1.058 & 0.430 & 0.016 \\
Distance of residence $\left(\mathrm{X}_{4}\right)$ & -0.026 & 0.057 & 0.644 \\
$\mathrm{C}$ & 65.15 & 6.202 & 0.000 \\
\hline
\end{tabular}

Source: Primary Data Processed (Eviews 9)

Based on the results of multiple linear regression, it is obtained the following equation:

$$
Y=65.15-0.502 X_{1}+0.051 X_{2}+1.058 X_{3}-0.026 X_{4}+c
$$

The interpretation of the results of above equation is in the form of the effect of member income, length of membership, education level and distance of residence on member participation. The first is the effect of member income on member participation. According to Slamet (1994:137), cooperative member participation is affected by level of member income. In addition, the result of previous study conducted by Sari (2015) indicated that member income has a significant effect on the participation of members of Koperasi Kartika Baladhika Jaya Kodim Jember. Based on the results of multiple regression test, it is obtained the value of -0.50 , meaning that if the income of members of Kopkun cooperative increases by one million, then the member participation will decrease by 10 person. Data processing using cross tabulation (crosstable) obtained the following results. 
Figure 2. Results Of Cross Tabulation Between Member Participation And Income

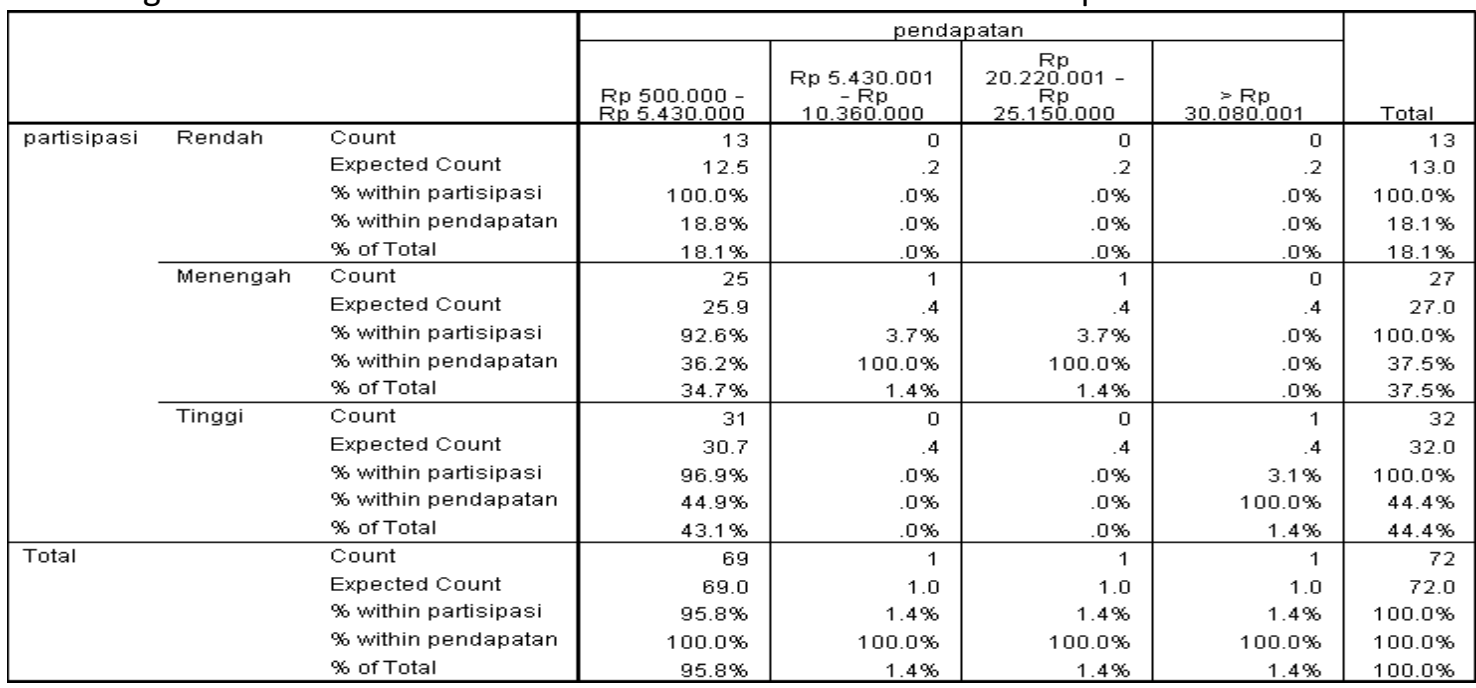

Source: Primary Data Processed (SPSS)

Based on Figure 2, it can be concluded that most members with high level of participation are those who earn between Rp500,000 - Rp5,430,000 of 31 people. Most of the high income respondents work as civil servants. During the study, most of the respondents working as civil servants prefer to save money in banks rather than cooperatives. The respondents argued that saving money in banks was more profitable, as interest rates of the bank were higher than in cooperatives. In addition, Yogi Permana working as an entrepeneur stated that he prefer to save money in the bank because cash withdrawal can be carried out easily through an ATM at any time, whereas cash withdrawal through cooperatives requires them to come directly to the cooperative and the time to cash withdrawal is limited to only working hours.

The average low-income respondents work as entrepreneurs and students. However, based on the results of this study, some respondents stated that they prefer to make savings in cooperatives due to the ease of the procedure, Afroni stated that "I prefer to save money in the cooperative rather than in a bank because I don't need to queue and the requirements are simple". In addition, Mrs. Darisem stated that "I prefer to shop at Kopkun rather than at a shop, I can get discounts shopping at Kopkun so that the the prices can be lower". Thus, it can be concluded that the level of participation of low-income respondents is higher than high-income respondents because the respondents prefer to allocate their income to shop and save money in the cooperative.

The second is the effect of length of membership on member participation. Based on the results of multiple regression test, it is obtained the value of -0.05 , meaning that if the length of membership increases by one month, then the member participation will decrease by 10 person. Data processing using cross tabulation obtained the following results. 
Figure 3. Results of Cross Tabulation Between Member Participation and Length of Membership

\begin{tabular}{|c|c|c|c|c|c|c|c|c|}
\hline & & & \multicolumn{5}{|c|}{ lama_menjadi_anggota } & \multirow[b]{2}{*}{ Total } \\
\hline & & & $1-20$ bulan & $21-40$ bulan & $41-60$ bulan & $101-120$ & $=121$ bulan & \\
\hline \multirow[t]{15}{*}{ partisipasi } & Rendah & Count & 3 & 3 & 3 & 3 & 1 & 13 \\
\hline & & Expected Count & 6.0 & 2.7 & 2.2 & 1.3 & .9 & 13.0 \\
\hline & & $\%$ within partisipasi & $23.1 \%$ & $23.1 \%$ & $23.1 \%$ & $23.1 \%$ & $7.7 \%$ & $100.0 \%$ \\
\hline & & $\begin{array}{l}\% \text { within } \\
\text { lama_menjadi_anggota }\end{array}$ & $9.1 \%$ & $20.0 \%$ & $25.0 \%$ & $42.9 \%$ & $20.0 \%$ & $18.1 \%$ \\
\hline & & $\%$ of Total & $4.2 \%$ & $4.2 \%$ & $4.2 \%$ & $4.2 \%$ & $1.4 \%$ & $18.1 \%$ \\
\hline & Menengah & Count & 12 & 5 & 6 & 2 & 2 & 27 \\
\hline & & Expected Count & 12.4 & 5.6 & 4.5 & 2.6 & 1.9 & 27.0 \\
\hline & & $\%$ within partisipasi & $44.4 \%$ & $18.5 \%$ & $22.2 \%$ & $7.4 \%$ & $7.4 \%$ & $100.0 \%$ \\
\hline & & $\begin{array}{l}\% \text { within } \\
\text { lama_menjadi_anggota }\end{array}$ & $36.4 \%$ & $33.3 \%$ & $50.0 \%$ & $28.6 \%$ & $40.0 \%$ & $37.5 \%$ \\
\hline & & $\%$ of Total & $16.7 \%$ & $6.9 \%$ & $8.3 \%$ & $2.8 \%$ & $2.8 \%$ & $37.5 \%$ \\
\hline & Tinggi & Count & 18 & 7 & 3 & 2 & 2 & 32 \\
\hline & & Expected Count & 14.7 & 6.7 & 5.3 & 3.1 & 2.2 & 32.0 \\
\hline & & $\%$ within partisipasi & $56.2 \%$ & $21.9 \%$ & $9.4 \%$ & $6.2 \%$ & $6.2 \%$ & $100.0 \%$ \\
\hline & & $\begin{array}{l}\text { \%o within } \\
\text { lama_menjadi_anggota }\end{array}$ & $54.5 \%$ & $46.7 \%$ & $25.0 \%$ & $28.6 \%$ & $40.0 \%$ & $44.4 \%$ \\
\hline & & $\%$ of Total & $25.0 \%$ & $9.7 \%$ & $4.2 \%$ & $2.8 \%$ & $2.8 \%$ & $44.4 \%$ \\
\hline \multirow[t]{5}{*}{ Total } & & Count & 33 & 15 & 12 & 7 & 5 & 72 \\
\hline & & Expected Count & 33.0 & 15.0 & 12.0 & 7.0 & 5.0 & 72.0 \\
\hline & & $\%$ within partisipasi & $45.8 \%$ & $20.8 \%$ & $16.7 \%$ & $9.7 \%$ & $6.9 \%$ & $100.0 \%$ \\
\hline & & $\begin{array}{l}\% \text { within } \\
\text { lama_menjadi_anggota }\end{array}$ & $100.0 \%$ & $100.0 \%$ & $100.0 \%$ & $100.0 \%$ & $100.0 \%$ & $100.0 \%$ \\
\hline & & 9 of Total & $45.8 \%$ & $20.8 \%$ & $16.7 \%$ & $9.7 \%$ & $6.9 \%$ & $100.0 \%$ \\
\hline
\end{tabular}

Source: Primary Data Processed (SPSS)

Based on Figure 3, it can be concluded that most members with high level of participation are those who have been members of the cooperative for 1-20 months of 18 members. Most members in the range of 1-20 months are students.

Clare Levay in Röpke (2003:43) stated that one of the problems in participation is a conflict of interest. During the study, the respondents who had long been members of the cooperative stated that they rarely contributed to the cooperative activities. In addition, they attended RAT without giving criticism and suggestions. This is because most respondents prioritize their individual interests. Darkum stated that "I am more concerned with personal interests, rather than having to attend a meeting as I prefer trading". Mrs. Luna Herawati working as a civil servant stated that "I rarely took part in cooperative activities or attended meetings because I was busy with office work".

The level of participation of student respondents who on average have only been members of the cooperative for one to two years is higher than the level of participation of respondents who have long been members of the cooperative. The level of participation of student respondents who on average have only been members of the cooperative for one to two years is higher than those who have long been members of the cooperative. This was evidenced by the student respondents stating that they frequently attended in cooperative activities, gave criticism and suggestion, attended and made valuable contributions to meetings by voicing opinions and contributing ideas or innovations to the cooperative.

The third is the effect of education level on member participation. According to Soemanto R,B (Khikmawati, 1997:28), the cooperative member participation is affected by education level. The higher education level of a person, the higher the level of participation. Previous study conducted by Sujianto (2012) found that education level has a positive effect on motivation in the cooperative. Based on the results of multiple regression test, it was obtained the value of 1.05 , meaning that if the education level of Kopkun members increases by one year, then the Kopkun member participation will increase by 12 person. Data processing using cross tabulation obtained the following results. 
Figure 4. Results of Cross Tabulation Between Member Participation and Education Level

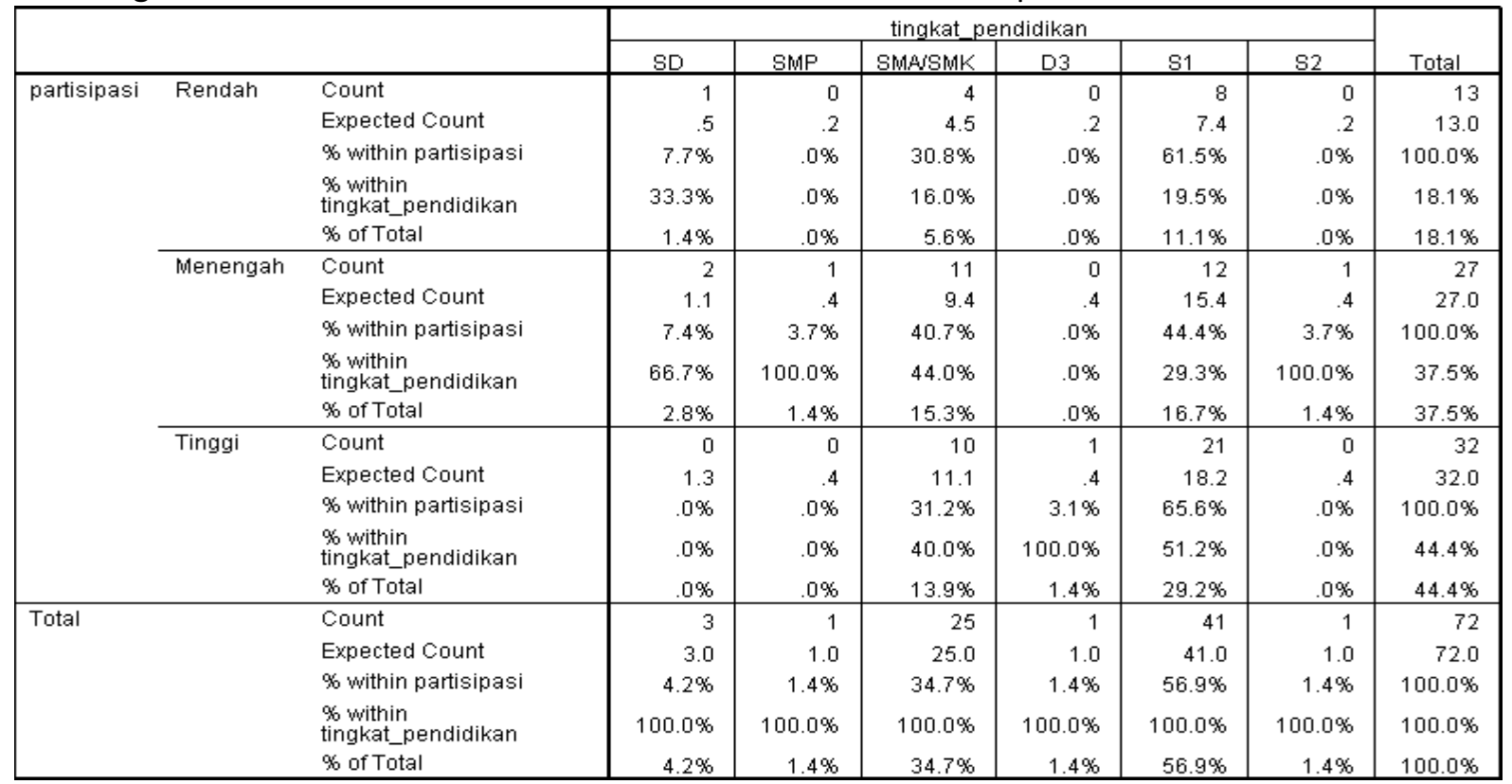

Source: Primary Data Processed (SPSS)

Based on Figure 4, it can be concluded that most members with high level of participation have education level of bachelor degree of 21 members. In this study, the level of participation of respondents working as entrepreneurs with the latest education level of elementary-high school is lower than the level of participation of respondents working as civil servants/private employees/students. This can be seen from its contributive participation. The respondents with higher education level often provide solutions related to problems in the cooperative, contribute new ideas and innovations, and provide criticism and suggestions for the cooperative.

The fourth is the effect of distance of residence on member participation. According to central place theory, the closer the market location to consumers, the higher the frequency of sales transaction. This means that the closer the distance of residence of members to the cooperative, the higher the level of participation. In addition, a study conducted by Meilani and Ismulyaty (2002) found that the distance of residence has a significant effect on the member participation. Based on the results of multiple regression test, it was obtained the value of -0.02 , meaning that if the distance of residence of Kopkun members increases by one kilometer, then the member participation will decrease by 10 person. Data processing using cross tabulation obtained the following results. 
Figure 5. Results of Cross Tabulation Between Member Participation and Distance of Residence

\begin{tabular}{|c|c|c|c|c|c|c|c|}
\hline & & & \multicolumn{4}{|c|}{ jarak_tempat_tinggal } & \multirow[b]{2}{*}{ Total } \\
\hline & & & $0,4-5,2 \mathrm{~km}$ & $5,3-10,1 \mathrm{~km}$ & $24,9-29,7 \mathrm{~km}$ & $29,8-34,6$ & \\
\hline \multirow[t]{15}{*}{ partisipasi } & Rendah & Count & 12 & 1 & 0 & 0 & 13 \\
\hline & & Expected Count & 11.9 & .7 & .2 & .2 & 13.0 \\
\hline & & $\%$ within partisipasi & $92.3 \%$ & $7.7 \%$ & $.0 \%$ & $.0 \%$ & $100.0 \%$ \\
\hline & & $\begin{array}{l}\text { \% within } \\
\text { jarak_tempat_tinggal }\end{array}$ & $18.2 \%$ & $25.0 \%$ & $.0 \%$ & $.0 \%$ & $18.1 \%$ \\
\hline & & $\%$ of Total & $16.7 \%$ & $1.4 \%$ & $.0 \%$ & $.0 \%$ & $18.1 \%$ \\
\hline & Menengah & Count & 26 & 1 & 0 & 0 & 27 \\
\hline & & Expected Count & 24.8 & 1.5 & .4 & .4 & 27.0 \\
\hline & & $\%$ within partisipasi & $96.3 \%$ & $3.7 \%$ & $.0 \%$ & $.0 \%$ & $100.0 \%$ \\
\hline & & $\begin{array}{l}\% \text { within } \\
\text { jarak_tempat_tinggal }\end{array}$ & $39.4 \%$ & $25.0 \%$ & $.0 \%$ & $.0 \%$ & $37.5 \%$ \\
\hline & & $\%$ of Total & $36.1 \%$ & $1.4 \%$ & $.0 \%$ & $.0 \%$ & $37.5 \%$ \\
\hline & Tinggi & Count & 28 & 2 & 1 & 1 & 32 \\
\hline & & Expected Count & 29.3 & 1.8 & .4 & .4 & 32.0 \\
\hline & & $\%$ within partisipasi & $87.5 \%$ & $6.2 \%$ & $3.1 \%$ & $3.1 \%$ & $100.0 \%$ \\
\hline & & $\begin{array}{l}\% \text { within } \\
\text { jarak_tempat_tinggal }\end{array}$ & $42.4 \%$ & $50.0 \%$ & $100.0 \%$ & $100.0 \%$ & $44.4 \%$ \\
\hline & & $\%$ of Total & $38.9 \%$ & $2.8 \%$ & $1.4 \%$ & $1.4 \%$ & $44.4 \%$ \\
\hline \multirow[t]{5}{*}{ Total } & & Count & 66 & 4 & 1 & 1 & 72 \\
\hline & & Expected Count & 66.0 & 4.0 & 1.0 & 1.0 & 72.0 \\
\hline & & $\%$ within partisipasi & $91.7 \%$ & $5.6 \%$ & $1.4 \%$ & $1.4 \%$ & $100.0 \%$ \\
\hline & & $\begin{array}{l}\% \text { within } \\
\text { jarak_tempat_tinggal }\end{array}$ & $100.0 \%$ & $100.0 \%$ & $100.0 \%$ & $100.0 \%$ & $100.0 \%$ \\
\hline & & $\%$ of Total & & & & & $100.0 \%$ \\
\hline
\end{tabular}

Source: Primary Data Processed (SPSS)

Based on Figure 5, it can be concluded that most members with high level of participation are those whose distance of residence is $0.4-5.2 \mathrm{~km}$ to the cooperative of 28 members. Based on the results of this study, seeing from the incentive participation, some respondents with distance of residence both near and far from the cooperative prefer shopping at the cooperative rather than shopping at the store closest to their residence. Endah, she was a respondent with the near distance of residence is stated that she prefers shopping at the cooperative because it has all the needed items available. According to Mrs. Tri, she was respondent with the near distance of residance is prefers shopping at the cooperative because the prices of items are lower and she can get discounted prices when purchasing in large quantities, so that it is more economical. The respondents living both near or far from the cooperative prefer to shop at the cooperative due to lower prices of items and discounted items. In addition, Okti, she who was a respondent with the furthest distance of residence to the cooperative stated that she prefers shopping at the cooperative, often participated in cooperative activities and member meetings. Thus, it can be concluded that the distance of residence did not have an effect on the cooperative member participation.

Hypothesis testing in this study used e F Test to determine whether the independent variables included in the model simultaneously have an effect on the dependent variable or not. The test obtained the following results.

Table 6. F Test

\begin{tabular}{ccc}
\hline F-statistic & F-table & P Value \\
\hline 4.51 & 2.50 & 0.0000542 \\
\hline
\end{tabular}

Source: Primary Data Processed (Eviews 9)

Based on Table 6, it is obtained $F_{\text {count }}$ value of 4.51 with Prob. value (F-statistic) of 0.002753 and $F_{\text {table }}$ value of 2.50 , meaning that the independent variables (member income, length of membership, education level and distance of residence) simultaneously have an effect on the dependent variable (member participation).

The next hypothesis testing is t-test to determine the extent of effect of one independent variable partially on the dependent variable. The test obtained the following results. 
Table 7. T-Test

\begin{tabular}{lcc}
\hline \multicolumn{1}{c}{ Independent Variable } & $\mathrm{T}_{\text {count }}$ & $\mathrm{T}_{\text {table }}$ ( $\alpha=5$ percent) \\
\hline Member income & -2.171 & -1.668 \\
Length of membership & -2.068 & -1.668 \\
Education level & 2.461 & 1.668 \\
Distance of residence to cooperative & -0.463 & -1.668 \\
\hline
\end{tabular}

Source: Primary Data Processed (Eviews 9)

The results of t-test in this study are that first, member income variable has a negative effect on the member participation because $t_{\text {count }}$ value is $-2.171<t_{\text {table }}$ value of -1.668 , so that $H_{0}$ is accepted and $\mathrm{H}_{1}$ is rejected, meaning that if member income increases, then the cooperative member participation decreases. Thus, the result of this study is in accordance with central place theory and Arayesh's study (2011) stating that member income variable has an effect on member participation.

Second, length of membership variable has a negative effect on member participation because tcount value is $-2.068<$ ttable of -1.668 , so that $\mathrm{HO}$ is accepted and $\mathrm{H} 1$ is rejected, meaning that if the length of membership increases, then the member participation decreases. Thus, the result of this study is in accordance with Slamet's study (1994:137) and Sari's study (2015) that length of membership variable has an effect on member participation, but in this study, length of membership variable has a negative effect on member participation.

Third, education level has a positive effect on member participation because tcount value is $2.461>$ ttable value of 1.668 , so that $\mathrm{HO}$ is rejected and $\mathrm{H} 1$ is accepted, meaning that if the education level of cooperative members is higher, then the level of participation increases. Thus, the result of this study is in accordance with Soemanto theory (Khikmawati, 1997:28) that education level variable has an effect on member participation.

Fourth, distance of residence variable has a negative effect on member participation, so that $\mathrm{HO}$ is rejected and $\mathrm{H} 1$ is accepted, meaning that the result of this study is not in accordance with central place theory and Meilani dan Ismulyaty's study (2002) because the distance of residence variable does not have an effect on member participation.

The next hypothesis testing is the coefficient of determination $\left(R^{2}\right)$ test to measure the extent of a model in explaining the variation of the dependent variable. The test obtained the following results.

Table 8. Determination of Coefficient $\left(R^{2}\right)$ Test

\begin{tabular}{ccc}
\hline$R-$ squared & Adjusted $R$ - squared & Std. error of regression \\
\hline 0.212146 & 0.165 & 9.250 \\
\hline
\end{tabular}

From the data processed using multiple linear regression, it is obtained the value of adjusted $R^{2}$ of 0.21 or 21 percent. This indicates that the independent variables (member income, length of membership, education level and distance of residence) of the model are able to explain the variation of the cooperative member participation (the dependent variable) by 21 percent.

This study used Elasticity test to analyze the most influential independent variable on the dependent variable. Based on the elasticity test, it was obtained the following results.

Table 9. Analysis Results of Elasticity Test

\begin{tabular}{lcc}
\hline & Variables & Elasticity \\
\hline Member income & $-0,018$ \\
Length of membership & -0.028 \\
Education level & 0.191 \\
Distance of residence & -0.002 \\
\hline
\end{tabular}

Source: Primary Data Processed (Eviews 9) 
Based on Table 9, it can be seen that the coefficient value of education level variable is greater than the coefficient values of member income, length of membership and distance of residence. This means that education level is the most influential variable on the member participation.

\section{CONCLUSION}

Based on the results of this study, it can be concluded that the variables of member income, length of membership, education level and distance of residence simultaneously had an effect on the member participation. However, the variable of distance of residence did not have a significant effect on the member participation and education level variable was the most influential variable on the member participation.

The implications of this study are that Kopkun needs to improve efficient services, for example through the provision of more items needed by consumers to stimulate the members to contribute to increasing capital and growth of the cooperative. The increase in the level of participation of Kopkun members can be performed through several ways such as giving bonuses or benefits to members whose deposits have reached the limit, involving old and new members in making decisions, policies and regulations regarding the cooperative. In addition, the government plays an important role in the development of the cooperative. The government can make efforts to develop the cooperative, such as providing guidance in the form of socialization, education and providing consulting assistance to the problems faced by the cooperative, carrying out determination and supervision of cooperative economic activities to compete with other business entities and providing facilities in the form of capital as well as developing business networks and cooperation.

For further studies, future studies are expected to be able to use other variables, so that the model will be better and able to explain the variable of member participation, to select more productive cooperatives selling more items needed by the consumers and the future researchers are expected to select inactive and problematic cooperatives as research materials.

\section{REFERENCES}

Arayesh, B. (2011). Identifying the Factors Affecting the Participation of Agricultural Cooperatives' Members. Journal of Agricultural and Biological Sciences. 6 (4): 560-566.

Central Statistics Agency. (2016). Tabel Perkembangan Koperasi pada Periode 1967-2015. Jakarta. Accessed on www.bps.go.id

Creswell, W. (2016). Research Design. Yogyakarta: Pustaka Pelajar.

Firdaus, M., Susanto, Edhi, A. (2002). Perkoperasian Sejarah, Teori dan Praktek. Jakarta: Ghalia Indonesia.

Glew, D.J., Anne, O'Leary-Kelly.M., Griffin, R.W. (1995). Participation in Organizations: A Preview of the Issues and Proposed Framework for Future Analysis. Journal Of Management. 21.

Gujarati, D. (2007) . Ekonometri Dasar. Terjemahan: Sumarno Zain. Jakarta: LP3ES.

Hasan, M.I. (2008). Pokok-Pokok Materi Statistik 1 (Statistik Deskriptif). Jakarta: Bumi Aksara.

Morrow, J. L., Hansen M.H., Pearson, A.W. (2004). The Cognitive and Affective Antecedents of General Trust Within Cooperative Organizations. Journal of Managerial Issues. 16. 48-64.

Khikmawati, M. (1997). Partisipasi orang tua murid melalui Bp3 dalam Membantu Penyelenggaan Pendidikan di STM Pembangunan di Yogyakarta. Makalah Komprehensif. FIP UNY.

Pengurus dan Badan Pengawas Kopkun. (2018). Sukses Koperasi Adalah Partisipasi. Purwokerto: Kopkun.

Meilani, A., Ismulyati, S. (2002). Hubungan Antara Faktor Anggota dan Partisipasi Terhadap Keberhasilan Usaha Koperasi di Kabupaten Bogor. Pondok Cabe.

Röpke, J. (2003). Ekonomi Koperasi Teori dan Manajemen. Jakarta: Salemba Empat.

Sari, T.R. (2015). Pengaruh Pendapatan dan Loyalitas Anggota terhadap Partisipasi Anggota dalam Pemanfaatan Pelayanan Jasa Simpan Pinjam dan Barang Konsumsi di Primer Koperasi (PRIMKOP) Kartika Baladhika Jaya Kodim 0824 Jember. Jurnal Ilmiah Mahasiswa. 1-7.

Slamet. (1994). Pembangunan Masyarakat Berwawasan Partisipasi. Surakarta: UNS Press. 
Sujianto. (2012). Pengaruh Pendidikan, Pelatihan dan Penyuluhan Terhadap Partisipasi Anggota Koperasi Pondok Pesantren. Journal of Socio-Religious Study. 6. 325-348.

Valentinov, V. (2007). Why Are Cooperatives Important In Agriculture? An Organizational Economics Perspective. Journal of Institutional Economics. 3. 55-69.

Zivkovic, S., Darren Hudson., Philip N. Johnson., John L. Park. (2017). The Impact of Managerial Behavior on Financial Performance of Agricultural Cooperatives. Journal of Cooperative. 32. 122. 